\title{
Protection from Oxygen Toxicity with Endotoxin
}

\author{
ROLE OF THE ENDOGENOUS ANTIOXIDANT ENZYMES OF THE LUNG
}

\author{
L. Frank, J. Summerville, and D. Massaro, The Pulmonary Toxicology \\ Laboratory, Veterans Administration Hospital and the Calvin and \\ Flavia Oak Asthma Research Center, University of Miami School of Medicine, \\ Miami, Florida 33101
}

\begin{abstract}
A B S T R A C T Endotoxin treatment of adult rats before hyperoxic exposure significantly increases their survival rate in $>95 \% \mathrm{O}_{2}(J$. Clin. Invest. 61: 269, 1978). In this study, we wished to determine: $(a)$ whether endotoxin would protect against $\mathrm{O}_{2}$ toxicity if it were administered after the animals were already in $>95 \%$ $\mathrm{O}_{2}$ for $12-48 \mathrm{~h}$; and $(b)$ the relationship between the endogenous antioxidant enzymes of the lung and the protective effect of endotoxin treatment.
\end{abstract}

Our results showed that adult rats given a single 500 $\mu \mathrm{g} / \mathrm{kg}$ dose of endotoxin up to $36 \mathrm{~h}$ after the onset of $\mathrm{O}_{2}$ exposure had significantly increased survival rates and decreased lung fluid accumulation compared to untreated animals in $\mathrm{O}_{2}(P<0.05)$. (Survival, 16/49 [untreated rats]; 18/20 [endotoxin at $12 \mathrm{~h}$ after the start of $\mathrm{O}_{2}$ exposure]; $25 / 26$ [endotoxin- $24 \mathrm{~h}$ ]; $15 / 20$ [endotoxin-36 h].)

Endotoxin-treated animals in $\mathrm{O}_{2}$ showed increases in pulmonary superoxide dismutase, catalase, and glutathione peroxidase activities before the usual time of onset of measurable pulmonary edema in untreated animals in $\mathrm{O}_{2}$. When diethyldithiocarbamate was used to block the superoxide dismutase enzyme rise in the endotoxin-treated rats in $\mathrm{O}_{2}$, the protective action of endotoxin against pulmonary $\mathrm{O}_{2}$ toxicity was nullified. In endotoxin-treated, $\mathrm{O}_{2}$-exposed mice, there were no lung antioxidant enzyme increases, and no protective effect from $\mathrm{O}_{2}$ toxicity was achieved.

We conclude that, in the rat, a single dose of endotoxin given even $36 \mathrm{~h}$ after the onset of hyperoxic exposure results in marked protection against $\mathrm{O}_{2}$-induced lung damage; and the increased lung antioxidant enzyme activity in the endotoxin-treated rats appears to be an essential component of this protective action.

\footnotetext{
A part of this study was presented at the Annual Meeting of the American Federation for Clinical Research, May 1979, Washington, D. C.

Received for publication 6 August 1979 and in revised form 29 November 1979.
}

\section{INTRODUCTION}

Small doses of bacterial endotoxin markedly increase the survival rate of adult rats exposed to normally lethal periods in hyperoxia, and significantly reduce the usual manifestations of acute pulmonary $\mathrm{O}_{2}$ toxicity (pulmonary edema, pleural effusion, and lung hemorrhage) (1-3). Unlike other agents reported to protect the lung from $\mathrm{O}_{2}$-induced injury, endotoxin requires no pretreatment period of several days before exposure to hyperoxia, but is effective even when administered in a single dose just before the onset of high $\mathrm{O}_{2}$ exposure (2).

We now report that the administration of a single dose of endotoxin at various intervals after the initiation of hyperoxic exposure provides protection against $\mathrm{O}_{2}$ toxicity. In addition, we have attempted to define the role of the endogenous antioxidant enzymes of the lung in mediating the protective effect against $\mathrm{O}_{2}$ toxicity in the endotoxin-treated animals. This was done in studies in which $(a)$ the time-course for pulmonary fluid accumulation and for changes in pulmonary antioxidant enzyme activities were monitored in endotoxintreated and untreated adult rats exposed to hyperoxia; (b) endotoxin was administered to mice, a species which does not respond to hyperoxic exposure with increased antioxidant enzyme activities; and $(c)$ the superoxide dismutase enzyme inhibitor, diethyldithiocarbamate $(\mathrm{DDC})^{1}$ was administered to endotoxintreated rats in $\mathrm{O}_{2}$.

\section{METHODS}

Animals and exposures. For these studies we used Sprague-Dawley albino rats $(225-275 \mathrm{~g})$ bred in the Animal Care Facility of the Veterans Administration Hospital, Miami, Fla.; and grey BLD2FIJ strain mice (25-30 g), obtained from Charles River Breeding Laboratories, Inc., Wilmington, Mass.

\footnotetext{
${ }^{1}$ Abbreviations used in this paper: CAT, catalase; DDC, diethyldithiocarbamate; GP, glutathione peroxidase; PBS, phosphate-buffered saline; SOD, superoxide dismutase.
} 
Exposures to $96-98 \% \mathrm{O}_{2}$ were conducted in 3.5-cu ft exposure chambers constructed from modified clear-plastic nursery isolettes (model 86, Air-Shields Inc., Hatboro, Pa.). Details of the monitored exposure conditions (96-98\% $\mathrm{O}_{2} ;<0.5 \% \quad \mathrm{CO}_{2} ; 22-25^{\circ} \mathrm{C} ; 60-80 \%$ humidity) have been described (3).

Animal studies. Endotoxin (Salmonella typhimurium lipopolysaccharide, phenol-water extraction, Sigma Chemical Co., St. Louis, Mo.) was dissolved in phosphate-buffered saline (PBS) and administered intraperitoneally in a total volume of $0.5 \mathrm{ml} / 100 \mathrm{~g}$ body wt. Control animals in $\mathrm{O}_{2}$ received equivolume injections of PBS. Air control animals received either similar dosages of endotoxin as the treated test animals in $\mathrm{O}_{2}$, or equivolume injections of PBS.

For the delayed-treatment studies, endotoxin was adminisstered in a single dose of $500 \mu \mathrm{g} / \mathrm{kg}$ i.p., at either zero time (just before placing the animals in hyperoxia), or at 12,24 , 36 , or $48 \mathrm{~h}$ after the start of hyperoxic exposure. Survival rate, lung fluid measurements, and antioxidant enzyme activities were determined on the surviving animals after $72 \mathrm{~h}$ in hyperoxia.

For the $\mathrm{O}_{2}$ toxicity, time-course studies in which lung fluid accumulation and antioxidant enzyme activity changes were monitored at intervals during $72 \mathrm{~h}$ exposure period, rats received a single injection of endotoxin or PBS at $24 \mathrm{~h}$ after the onset of $\mathrm{O}_{2}$ exposure. Groups of four animals each were then removed at 12 -h intervals for lung fluid measurements and for lung enzyme analyses.

For the superoxide dismutase inhibition studies with DDC, rats received a single $500-\mu \mathrm{g} / \mathrm{kg}$ injection of endotoxin at zero time; a subgroup of these animals also received DDC $(100 \mathrm{mg} / \mathrm{kg}$ i.p., dissolved in PBS) at zero time and after $24 \mathrm{~h}$ of $\mathrm{O}_{2}$ exposure. For the DDC experiments, an $\mathrm{O}_{2}$ exposure of only $48 \mathrm{~h}$ was used because of the high mortality rate after this time.

In the mouse studies, animals received $500-\mu \mathrm{g} / \mathrm{kg}$ doses of endotoxin at zero time, and at 24 and $48 \mathrm{~h}$ into the 120 -h exposure period. Eight mice each from the treated and untreated groups were removed after 72 and $96 \mathrm{~h}$ of exposure time for lung analyses.

Analyses. All animals were killed by exsanguination under pentobarbital anesthesia. Pleural fluid accumulation was measured by absorbing the fluid in the chest cavities with preweighed gauze pads, assuming unit density $(1 \mathrm{~g}=1 \mathrm{ml})$. Lung wet weight per body weight measurements were based on the individual animal's body weight at the start of the exposure period. Lung dry weight was determined when a stable lung weight was recorded after drying the lungs for several days in a $60^{\circ} \mathrm{C}$ oven.

Superoxide dismutase (SOD) (4), catalase (CAT) (5), glutathione peroxidase (GP) (6), protein (7), and DNA (8) were measured in lungs perfused free of blood with cold isotonic buffer $(0.1 \mathrm{M}$ potassium phosphate, $0.15 \mathrm{M}$ potassium chloride, $\mathrm{pH} \mathrm{7.4)}$ and homogenized in cold hypotonic buffer $(0.005 \mathrm{M}$ potassium phosphate, $\mathrm{pH} 7.8), 1: 10$ (wt/vol), in a Brinkman Polytron (Brinkmann Instruments, Westbury, N. Y.). CAT and GP enzyme activities were measured on the $15,000 \mathrm{~g}$ lung supernatant fluid stored frozen overnight. SOD enzyme activity (combined cytosolic or $\mathrm{Cu}-\mathrm{Zn}-\mathrm{SOD}$ and mitochondrial or Mn-SOD, as measured by the cytochrome $c$ assay) was determined on fresh lung homogenates.

Statistical analyses. The Student's group $t$ test and the Fisher exact nonparametric test were used for statistical analyses (9). Typically, the data from two or three experiments (with $n=4$ animals per treatment group per experiment for nearly all the studies) were pooled after the validity of data-pooling was established by the chi-square test for homogeneity. A $P$ value of $<0.05$ was used for assigning statistical significance.

\section{RESULTS}

Effect of time of administration of endotoxin on survical and lung fluid accumulation. Administration of endotoxin at zero time or at 12 or $24 \mathrm{~h}$ after the start of $\mathrm{O}_{2}$ exposure resulted in nearly $100 \%$ survival of the treated animals at the end of the $72 \mathrm{~h} \mathrm{O} \mathrm{O}_{2}$ challenge period (Fig. 1). $75 \%$ of the rats receiving a single dose of endotoxin after $36 \mathrm{~h}$ of $\mathrm{O}_{2}$ exposure survived. All these treatment groups had statistically significant increases in survival rate compared to the $33 \%$ survival rate of the untreated $\mathrm{O}_{2}$ control group $(P<0.05)$. No increase in survival resulted with endotoxin treatment given after $48 \mathrm{~h}$ in hyperoxia (35\% survival rate).

All the $\mathrm{O}_{2}$-exposed animals showed evidence of lung and pleural fluid accumulation compared to the air control animals (Table I). However, pleural effusion and lung edema (lung weight per body weight and lung dry weight per wet weight measurements) was significantly less in the animals that received endotoxin at $0-36 \mathrm{~h}$ of exposure compared to the untreated $\mathrm{O}_{2}$-exposed group $(P<0.05)$.

Time-course for development of pulmonary edema and rise in antioxidant enzyme activity. After $36 \mathrm{~h}$ of exposure to $96-98 \% \quad \mathrm{O}_{2}$ there was no evidence of pleural effusion or edema in either experimental group (Table II). However, by $48 \mathrm{~h}$ of $\mathrm{O}_{2}$ exposure the untreated rats show some increase in pleural effusion and significant pulmonary edema, as reflected in the decrease in lung dry:wet weight ratio $(P<0.05)$. In

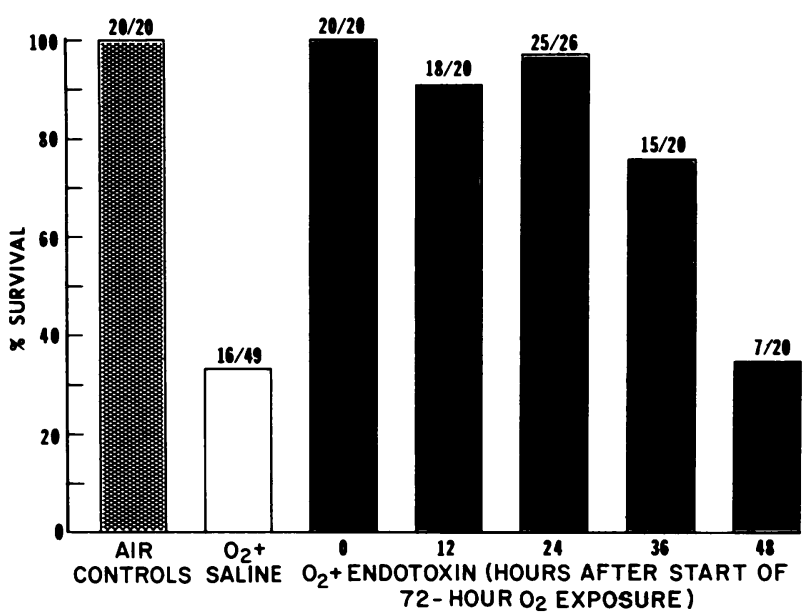

FigurE 1 Effect of delayed endotoxin treatment on survival of adult rats exposed to hyperoxia $\left(96-98 \% \mathrm{O}_{2}, 72 \mathrm{~h}\right)$. Animals were treated with a single $500 \mu \mathrm{g} / \mathrm{kg}$ dose of endotoxin, intraperitoneally, either at zero time (just before being placed in hyperoxia) or at $12,24,36$, or $48 \mathrm{~h}$ after the onset of $\mathrm{O}_{2}$ exposure. $\mathrm{O}_{2}$ control group received equivolume PBS and air-controls received either endotoxin or equivolume $\mathrm{PBS}$ at zero time. Survival rates for air-control group and endotoxin groups $0,12,24,36 \mathrm{~h}$ are all significantly greater than $\mathrm{O}_{2}$-control group survival rate, $P<0.05$. 
TABLE I

Lung Fluid Accumulation in Adult Rats Exposed to Hyperoxia: Effects of Delayed Treatment with Endotoxin*

\begin{tabular}{lccc}
\hline \multicolumn{1}{c}{ Treatment } & Pleural fluid & Lung weight per body weight & Lungdry weight per wet weight \\
\hline & $m l$ & $\%$ & \\
Air-control & $0.19 \pm 0.03 \ddagger$ & $0.505 \pm 0.043 \ddagger$ & $0.202 \pm 0.006 \ddagger$ \\
$\mathrm{O}_{2}$ saline & $10.80 \pm 3.03$ & $0.895 \pm 0.151$ & $0.170 \pm 0.010$ \\
$\mathrm{O}_{2}$ endotoxin, $\mathrm{O} \mathrm{h}$ & $2.59 \pm 1.65 \ddagger$ & $0.708 \pm 0.021 \ddagger$ & $0.181 \pm 0.010$ \\
$\mathrm{O}_{2}$ endotoxin, $12 \mathrm{~h}$ & $1.27 \pm 1.61 \ddagger$ & $0.700 \pm 0.040 \ddagger$ & $0.181 \pm 0.008$ \\
$\mathrm{O}_{2}$ endotoxin, $24 \mathrm{~h}$ & $0.27 \pm 0.13 \ddagger$ & $0.708 \pm 0.043 \ddagger$ & $0.186 \pm 0.006 \ddagger$ \\
$\mathrm{O}_{2}$ endotoxin, $36 \mathrm{~h}$ & $0.21 \pm 0.06 \ddagger$ & $0.720 \pm 0.044 \ddagger$ & $0.184 \pm 0.010 \ddagger$ \\
$\mathrm{O}_{2}$ endotoxin, $48 \mathrm{~h}$ & $1.44 \pm 1.03 \ddagger$ & $0.973 \pm 0.033$ & $0.169 \pm 0.010$ \\
\hline
\end{tabular}

* Adult rats exposed to $96-98 \% \mathrm{O}_{2}$ for $72 \mathrm{~h}$. Animals received a single $500 \mu \mathrm{g} / \mathrm{kg}$ dose of endotoxin, intraperitoneally, at either zero time (just before being placed in hyperoxia) or at 12,24 , 36 , or $48 \mathrm{~h}$ after the onset of $\mathrm{O}_{2}$ exposure. Air controls received either endotoxin or equivolume PBS. Results expressed as mean value \pm SEM for two or three experiments $(n=8-10$ animals per treatment group).

\$ Significant difference from the $\mathrm{O}_{2}$ saline (untreated) group, $P<0.05$.

contrast, the endotoxin-treated animals show no pleural effusion at $48 \mathrm{~h}$ of exposure time and a nonsignificant change in lung dry per wet weight measurements compared to the air control group. In addition, there is no further lung fluid accumulation during the remaining $24 \mathrm{~h}$ in $96-98 \% \mathrm{O}_{2}$ in the endotoxin-treated group, in contrast to the progressive fluid accumulation that occurs in the untreated animals. Table III shows there is already an increase in lung antioxidant enzyme activity at $36 \mathrm{~h}$ in the $\mathrm{O}_{2}$-exposed, endotoxin-treated rats. This increase precedes by $12 \mathrm{~h}$ the first evidence of an increase in pleural fluid or lung water (Table II). SOD, CAT, and GP enzyme activities are significantly elevated above control levels at $60 \mathrm{~h}$ of exposure. The untreated $\mathrm{O}_{2}$-exposed rats demonstrate no significant changes in lung enzyme activity compared to the air control animals (except for an increase in CAT activity at the 60 -h time point).

Endotoxin treatment in mice. The lung antioxidant enzyme activities in the endotoxin-treated mice (unlike in the endotoxin-treated rats) did not increase during hyperoxic exposure (Table IV). Endotoxin treatment, in the scheduled dosage, had no effect on the survival rate of mice exposed to prolonged hyperoxia or on the accumulation of lung fluid. Enzyme activities measured at $72 \mathrm{~h}$ of exposure time were also unchanged in the endotoxin-treated and untreated groups, and lungs from both groups were equally edematous (not shown).

The effect of SOD inhibitor (DDC) treatment. Treatment with DDC reversed the protective effect of endotoxin ( $48 \mathrm{~h}$ survival, $40 \mathrm{vs}$. $100 \%$ with endotoxin

TABLE II

Time-Course Study: Lung Fluid Accumulation in Adult Rats Exposed to Hyperoxia*

\begin{tabular}{lcccc}
\hline \multicolumn{2}{c}{$h \ldots \ldots \ldots \ldots \ldots$} & \multicolumn{1}{c}{46} & \multicolumn{1}{c}{60} & \multicolumn{1}{c}{72} \\
\hline Pleural fluid & & & $m l$ \\
Air control & $0.13 \pm 0.03$ & $0.17 \pm 0.05$ & $0.15 \pm 0.04 \ddagger$ & $0.17 \pm 0.04 \ddagger$ \\
$\mathrm{O}_{2}$ saline & $0.14 \pm 0.03$ & $0.47 \pm 0.57$ & $6.53 \pm 3.05$ & $8.65 \pm 1.64$ \\
$\mathrm{O}_{2}$ endotoxin & $0.09 \pm 0.05$ & $0.15 \pm 0.07$ & $0.41 \pm 0.62 \ddagger$ & $0.51 \pm 0.53 \ddagger$ \\
Lung dry weight per wet weight & & & \\
Air control & $0.200 \pm 0.006$ & $0.200 \pm 0.006 \ddagger$ & $0.199 \pm 0.006 \ddagger$ & $0.200 \pm 0.007 \ddagger$ \\
$\mathrm{O}_{2}$ saline & $0.201 \pm 0.004$ & $0.175 \pm 0.008$ & $0.162 \pm 0.005$ & $0.175 \pm 0.006$ \\
$\mathrm{O}_{2}$ endotoxin & $0.198 \pm 0.006$ & $0.186 \pm 0.006$ & $0.185 \pm 0.004 \ddagger$ & $0.185 \pm 0.004 \ddagger$
\end{tabular}

* Adult rats exposed to $96-98 \% \mathrm{O}_{2}$ for $36,48,60$, or $72 \mathrm{~h}$. Treated animals received a single 500 $\mu \mathrm{g} / \mathrm{kg}$ dose of endotoxin, intraperitoneally, at $24 \mathrm{~h}$ after the onset of $\mathrm{O}_{2}$ exposure. Air controls received either endotoxin or equivolume PBS. Results expressed as mean value \pm SEM for two experiments ( $n=8$ animals per treatment group).

\$ Significant difference from $\mathrm{O}_{2}$ saline (untreated) group, $P<0.05$. 
TABLE III

Time-Course Study: Lung Antioxidant Enzyme Activity in Adult Rats Exposed to Hyperoxia*

\begin{tabular}{|c|c|c|c|}
\hline \multirow[b]{2}{*}{ Treatment } & \multicolumn{3}{|c|}{$36 \mathrm{~h}$ Exposure } \\
\hline & SOD & CAT & GP \\
\hline & Ullung & IUllung & $\mu M$ NADPH oxid/min/lung \\
\hline Air control & $691 \pm 104$ & $7,540 \pm 1,828$ & $42.6 \pm 3.2$ \\
\hline $\mathrm{O}_{2}$ saline & $655 \pm 139$ & $6,566 \pm 2,455$ & $42.6 \pm 8.7$ \\
\hline \multirow[t]{2}{*}{$\mathrm{O}_{2}$ endotoxin } & $\begin{array}{c}786 \pm 93 \\
(+14 \%)\end{array}$ & $\begin{array}{c}8,104 \pm 1,057 \\
(+7 \%)\end{array}$ & $\begin{array}{r}51.0 \pm 7.0 \\
(+20 \%)\end{array}$ \\
\hline & \multicolumn{3}{|c|}{$60 \mathrm{~h}$ Exposure } \\
\hline Air control & $631 \pm 63$ & $6,190 \pm 976$ & $36.9 \pm 6.6$ \\
\hline $\mathrm{O}_{2}$ saline & $596 \pm 41$ & $7,630 \pm 1,332 \ddagger$ & $43.2 \pm 8.4$ \\
\hline $\mathrm{O}_{2}$ endotoxin & $\begin{array}{c}958 \pm 96 \ddagger \\
(+52 \%)\end{array}$ & $\begin{array}{c}9,490 \pm 1,890 \ddagger \\
(+53 \%)\end{array}$ & $\begin{array}{c}66.3 \pm 6.0 \ddagger \\
(+80 \%)\end{array}$ \\
\hline
\end{tabular}

* Adult rats exposed to $96-98 \% \mathrm{O}_{2}$ for 36 or $60 \mathrm{~h}$. Treated animals received a single $500 \mu \mathrm{g} / \mathrm{kg}$ dose of endotoxin, intraperitoneally, at $24 \mathrm{~h}$ after the onset of $\mathrm{O}_{2}$ exposure. Air controls received either endotoxin or equivolume phosphate-buffered saline. Results expressed as mean \pm SEM for two experiments $(n=8$ animals per treatment group). Values in parentheses are the percent increase in enzyme activity compared to air control values.

† Significant difference from air control enzyme value, $P<0.05$.

treatment alone) (Table V). The DDC plus endotoxintreated animals manifested the usual pulmonary signs of acute experimental $\mathrm{O}_{2}$ toxicity including pulmonary edema, pleural effusion, and areas of lung hemorrhage.
No such findings were evident in animals treated with DDC alone or with endotoxin plus DDC while being maintained in room air (survival, 17/17) (Table V).

Whereas the animals given endotoxin alone did show

\section{TABLE IV}

Survival, Pulmonary Edema, and Lung Antioxidant Enzyme Activity in Adult Mice Exposed to Hyperoxia*

\begin{tabular}{|c|c|c|c|c|c|}
\hline Treatment & Survivalt & Body wt & Lung wt & $\begin{array}{l}\text { Lung wt per } \\
\text { body wt }\end{array}$ & $\begin{array}{l}\text { Lungdry wt per } \\
\text { wet wt }\end{array}$ \\
\hline & $\%$ & $g$ & g & $\%$ & \\
\hline Air control & $24 / 24(100)$ & 27.74 & 0.147 & 0.532 & 0.221 \\
\hline $\mathrm{O}_{2}$ saline & $29 / 41(71)$ & $21.97 \S$ & $0.322 \S$ & $1.470 \$$ & $0.145 \S$ \\
\hline $\mathrm{O}_{2}$ endotoxin & $29 / 40(73)$ & $21.54 \S$ & $0.376 \S$ & $1.729 \S$ & $0.132 \S$ \\
\hline Treatment & \multicolumn{2}{|c|}{ SOD } & \multicolumn{2}{|c|}{ CAT } & GP \\
\hline & \multicolumn{2}{|c|}{ Ullung } & \multicolumn{2}{|c|}{ IU/lung } & $\begin{array}{c}\text { uM NADPH } \\
\text { oxid/min/lung }\end{array}$ \\
\hline Air control & \multicolumn{2}{|c|}{$109 \pm 6$} & \multicolumn{2}{|c|}{$1,922 \pm 387$} & $5.67 \pm 0.67$ \\
\hline $\mathrm{O}_{2}$ saline & \multicolumn{2}{|c|}{$97 \pm 9$} & \multicolumn{2}{|c|}{$1,393 \pm 410$} & $5.15 \pm 1.16$ \\
\hline $\mathrm{O}_{2}$ endotoxin & \multicolumn{2}{|c|}{$96 \pm 11$} & \multicolumn{2}{|c|}{$1,435 \pm 380$} & $5.92 \pm 0.74$ \\
\hline
\end{tabular}

* Adult mice exposed to $96-98 \% \mathrm{O}_{2}$ for $96 \mathrm{~h}$. Treated animals received $500 \mu \mathrm{g} / \mathrm{kg}$ of endotoxin, intraperitoneally, at zero time (just before being placed in hyperoxia) and at 24 and $48 \mathrm{~h}$ after the onset of $\mathrm{O}_{2}$ exposure. Air controls received endotoxin or equivolume PBS. Results for edema measurements are mean values for a single experiment with $n=4$ animals per treatment group (standard variations omitted to avoid over-cluttering of table). Results for enzymes are mean values $\pm \mathrm{SD}$ for a single experiment with $n=4$ animals per treatment group. f Survival at $120 \mathrm{~h}: \mathrm{O}_{2}$ saline, $1 / 29(3 \%)$ and $\mathrm{O}_{2}$ endotoxin, $2 / 29(6 \%)$.

$\S$ Significant difference from air control value, $P<0.05$. 
TABLE V

Survival and Lung Fluid Accumulation in Adult Rats Exposed to Hyperoxia: Effects of Endotoxin Treatment $\pm D D C^{*}$

\begin{tabular}{lccc}
\hline \multicolumn{1}{c}{ Treatment } & Survival & Pleural fluid & Lungdry wt per wet wt \\
\hline & $\%$ & $m l$ & \\
Air saline & $15 / 15(100)$ & $0.20 \pm 0.02$ & $0.194 \pm 0.002$ \\
Air endotoxin + DDC & $17 / 17(100)$ & $0.13 \pm 0.06$ & $0.195 \pm 0.004$ \\
$\mathrm{O}_{2}$ endotoxin & $17 / 17(100)$ & $0.15 \pm 0.07$ & $0.179 \pm 0.007$ \\
$\mathrm{O}_{2}$ endotoxin + DDC & $14 / 35(40) \ddagger$ & $4.68 \pm 2.49 \ddagger$ & $0.161 \pm 0.003 \ddagger$ \\
\hline
\end{tabular}

* Adult rats exposed to $96-98 \% \mathrm{O}_{2}$ for $48 \mathrm{~h}$. Animals received a single $500 \mu \mathrm{g} / \mathrm{kg}$ dose of endotoxin, intraperitoneally, at zero time (just before being placed in $\mathrm{O}_{2}$ ) \pm DDC, $100 \mathrm{mg} / \mathrm{kg}$ i.p., at zero time and at $24 \mathrm{~h}$ after the onset of $\mathrm{O}_{2}$ exposure. Results expressed as mean values \pm SEM for two experiments ( $n=8$ animals per treatment group).

$\$$ Significant difference from all other treatment groups, $P<0.05$.

significantly increased pulmonary SOD activity after $48 \mathrm{~h}$ in $\mathrm{O}_{2}$ (Table VI), those given endotoxin plus DDC showed no increase in lung SOD activity. CAT and GP activities were increased in both groups of animals, and the changes were greater in the endotoxin-treated group than in the group receiving combined drug treatment. (The enzyme results in Table VI have been expressed as per milligram DNA instead of on a per lung basis. This is because whole lungs were not used for enzyme analyses in these experiments and because of the hemorrhagic changes in the lungs of endotoxin plus DDC animals in $\mathrm{O}_{2}$, which would seriously influence the enzyme values expressed on a per lung basis due to erythrocyte enzyme contamination.)

\section{DISCUSSION}

Comparison between endotoxin and other treatment modalities which protect against hyperoxia. Agents such as alpha naphthylthiourea, oleic acid, vitamin E, and the "tolerance" to $100 \% \mathrm{O}_{2}$ induced by first preexposing rats to sublethal concentrations of $\mathrm{O}_{2}$, all require several days of pretreatment to achieve a protective effect against $\mathrm{O}_{2}$-induced lung injury and lethality $(2,10-12)$. Also, whereas each of these other protectants may result in increased survival rates in hyperoxia, they do not prevent substantial lung damage from occurring, as assessed by histological examination after $\mathrm{O}_{2}$ exposures (10-12). In contrast, endotoxin provides protection without requiring any pretreatment interval before exposure to hyperoxia, and the endotoxin-treated animals show minimal lung alterations after exposure to similar hyperoxic challenge (1-3).

Furthermore, a single small dose of endotoxin (500) $\mu \mathrm{g} / \mathrm{kg}$, equivalent to $\sim 1 / 40$ th of the median lethal dose for the species), (an provide significant protection to hyperoxic-exposed animals even when it is administered as late as $24-36 \mathrm{~h}$ after the onset of high $\mathrm{O}_{2}$ exposure (Fig. 1, Table I). We are unaware of any other experimental agent that is able to provide such

TABLE VI

Lung Antioxidant Enzyme Activity in Adult Rats Exposed to Hyperoxia: Effects of Endotoxin Treatment $\pm D D C^{*}$

\begin{tabular}{|c|c|c|c|}
\hline Treatment & SOD & CAT & GP \\
\hline & C $/ \mathrm{mg} D \mathrm{NA}$ & $I C / m g D N A$ & u.MNADPH oxid/min/mg DNA \\
\hline Air saline & $53.5 \pm 8.3$ & $504 \pm 65$ & $5.21 \pm 0.56$ \\
\hline Air endotoxin + DDC & $53.1 \pm 5.7$ & $564 \pm 89$ & $5.26 \pm 0.69$ \\
\hline $\mathrm{O}_{2}$ endotoxin & $76.3 \pm 10.8 \ddagger$ & $860 \pm 124$ & $7.73 \pm 0.83 \ddagger$ \\
\hline $\mathrm{O}_{2}$ endotoxin + DDC & $51.7 \pm 5.2$ & $765 \pm 76$ & $6.79 \pm 0.46$ \\
\hline
\end{tabular}

* Adult rats exposed to $96-98 \% \mathrm{O}_{2}$ for 48 hours. Animals received a single $500 \mu \mathrm{g} / \mathrm{kg}$ dose of endotoxin, intraperitoneally, at zero time (just before being placed in $\mathrm{O}_{2}$ ) \pm DDC, $100 \mathrm{mg} / \mathrm{kg}$ i.p., at zero time and at $24 \mathrm{~h}$ after the onset of $\mathrm{O}_{2}$ exposure. Results expressed as mean values \pm SEM for two experiments $(n=6-8$ animals per treatment group).

I Significant difference from both air control groups, $P<0.0 .5$. 
protection when administered after the exposure period has begun.

Evidence that the protective effect of endotoxin is dependent upon increased pulmonary antioxidant enzyme activity. The mechanism of action of endotoxin in the hyperoxic setting is not known. In untreated neonatal animals, protection from $\mathrm{O}_{2}$-induced severe lung damage, lung fluid accumulation, and lethality is correlated with the ability of the neonatal animal to mount a rapid lung antioxidant enzyme response to $\mathrm{O}_{2}$ challenge (13-15). Untreated adult rats exposed directly to $95-100 \% \mathrm{O}_{2}$ usually succumb within $60-72$ $h$, and no change in lung SOD, CAT, and GP enzyme activities are found $(13,14)$. Similar findings have been reported for adult primates exposed to $95 \% \mathrm{O}_{2}$ (16). Adult rats preexposed for several days to $85 \%$ $\mathrm{O}_{2}$ show increased lung SOD activity, and on subsequent exposure to $100 \% \mathrm{O}_{2}$ demonstrate prolonged survival $(10,12,17)$. Endotoxin-treated adult rats have lung biochemical responses to $\mathrm{O}_{2}$ exposure which are very similar to the adaptive responses of neonatal animals, i.e., significant rapid increases in lung SOD, CAT, and GP have been consistently observed in response to hyperoxic challenge (1).

We consider the following as important evidence that the endogenous antioxidant enzyme system response to hyperoxia in the endotoxin-treated animals is essential to the protective action of this agent: $(a)$ Increases in lung SOD, CAT, and GP activities occur in endotoxin-treated animals $12 \mathrm{~h}$ before the onset of progressive pulmonary edema in untreated animals in $\mathrm{O}_{2} ;(b)$ DDC interferes with the expected increase in SOD enzyme activity in endotoxin-treated rats in response to hyperoxia and nullifies the usual protective action of endotoxin; $(c)$ In the dosage regimen we used, endotoxin treatment concomitantly fails to elicit an increase in lung antioxidant enzymes in mice and fails to protect mice against $\mathrm{O}_{2}$-induced lung edema and lethality.

DDC treatment alone has not been associated with evidence of lung toxicity $(15,18$; Table V). It should be kept in mind, however, that DDC is not a specific inhibitor for SOD, but also inhibits other coppercontaining enzymes such as aldehyde dehydrogenase, xanthine oxidase, dopamine $\beta$-hydroxylase, and cytochrome $c$ oxidase $(15,19)$. None of these other enzymes is believed to be directly involved in the $\mathrm{O}_{2}$ toxicity process, but cytochrome $c$ oxidase is the only one that has been systematically studied. The activity of this enzyme in the lungs appears to be unaffected by hyperoxic exposure $(15,20)$.

It is possible that the endotoxin dosage selected in the mouse study (comparable to the rat dose of $\sim 1 / 40-1 / 50$ th of the median lethal dose) was insufficient to provide protection in this species. There is known to be a great difference in the sensitivity of different species to the biological actions of endotoxin, however, the mouse and the rat sensitivities are reported to be very similar (21).

Unanswered questions. The mechanism by which endotoxin treatment results in a rise in antioxidant enzymes in rats exposed to hyperoxia is unclear. Endotoxin is a mitogen for certain cells including reticuloendothelial cells, B lymphocytes, and also liver cells $(22,23)$. Studies in our laboratory (with Dr. Ming-Jen Chiang) have shown significant increases in lung DNA content within $24 \mathrm{~h}$ of endotoxin treatment. Furthermore, islands of cuboidal alveolar lining cells resembling type II cells have been observed in the lungs of endotoxin-treated, $\mathrm{O}_{2}$-exposed rats $(1-3)$. Thus, the type II cells, which seem to have innate resistance to hyperoxia, may be stimulated to proliferate by endotoxin and may represent the cell source for the increased antioxidant enzyme activities in treated adult rats. This notion is supported by the demonstration that hyperoxic exposure of isolated type II cells produces increased SOD activity in these cells $(24,25)$.

In addition to its apparent mitogenic effect on the lung, endotoxin treatment of rats exposed to hyperoxia results in an increase in the ratio of RNA to DNA in the lung. ${ }^{2}$ This suggests the possibility that in addition to acting as a mitogen, endotoxin in some manner "activates" lung cells and facilitates a biosynthetic response to the increase in $\mathrm{O}_{2}^{-}$substrate which is present under hyperoxic conditions and which is reported to be the direct biological stimulus for SOD induction $(26,27)$. Currently, we are investigating this proposed mechanism of action of endotoxin on the adaptive response of the lung to $\mathrm{O}_{2}$ challenge.

\section{ACKNOWLEDGMENTS}

The authors express their appreciation to Teresa Rosario and Ondina Garcia-Pons for their assistance in the preparation of this manuscript.

This work was supported in part by National Institutes of Health grants HL07283, HL20366 and Veterans Administration funds.

\section{REFERENCES}

1. Frank, L., J. Yam, and R. J. Roberts. 1978. The role of endotoxin in protection of adult rats from high oxygen lung toxicity. J. Clin. Invest. 61: 269-275.

2. Frank, L. and R. J. Roberts. 1979. Endotoxin protection against oxygen-induced acute and chronic lung injury. J. Appl. Physiol. 47: 577-581.

3. Frank, L., and R. J. Roberts. 1979. Oxygen toxicity: protection of the lung by bacterial lipopolysaccharide (endotoxin). Toxicol. Appl. Pharmacol. 50: 371-380.

4. McCord, J. M., and I. Fridovich. 1969. Superoxide dismutase: an enzymatic function for erythrocuprein (hemo(uprein). J. Biol. Chem. 244: 6049-6055.

\footnotetext{
${ }^{2}$ Unreported data from Dr. Ming-Jen Chiang.
} 
5. Holmes, R. S., and C. J. Masters. 1970. Epigenetic interconversion of the multiple forms of mouse liver catalase. FEBS (Fed. Eur. Biochem. Soc.) Lett. 11: 45-48.

6. Paglia, D. E., and W. N. Valentine. 1967. Studies on the quantitative and qualitative characterization of erythrocyte glutathione peroxidase. J. Lab. Clin. Med. 70: 158-169.

7. Schacterle, G. R., and R. L. Pollack. 1973. A simplified method for the quantitative assay of small amounts of protein in biological material. Anal. Biochem. 51: $654-655$.

8. Richards, G. M. 1974. Modifications of the diphenylamine reactions giving increased sensitivity and simplicity in the estimation of DNA. Anal. Biochem. 57: 369-376.

9. Steel, R. G., and J. H. Torrie. 1960. Principles and Procedures of Statistics. McGraw-Hill Book Co., Inc., New York.

10. Tierney, D. F., L. Ayers, and R. S. Kasuyama. 1977. Altered sensitivity to oxygen toxicity. Am. Rev. Resp. Dis. 115: 59-65.

11. Smith, G., P. M. Winter, and R. F. Wheelis. 1973. Increased normobaric oxygen tolerance of rabbits following oleic acid-induced lung damage. J. Appl. Physiol. 35: 395-400.

12. Crapo, J. D., and D. F. Tierney. 1974. Superoxide dismutase and pulmonary oxygen toxicity. Am. J. Physiol. 226: 1401-1407.

13. Yam, J., L. Frank, and R. J. Roberts. 1978. Oxygen toxicity: comparison of lung biochemical response in neonatal and adult rats. Pediatr. Res. 12: 115-119.

14. Frank, L., J. R. Bucher, and R. J. Roberts. 1979. Oxygen toxicity in neonatal and adult animals of various species. J. Appl. Physiol. 45: 699-704.

15. Frank, L., D. Wood, and R. J. Roberts. 1978. The effect of diethyldithiocarbamate (DDC) on oxygen toxicity and lung enzyme activity in immature and adult rats. Biochem. Pharmacol. 27: 251-254.

16. Robinson, L. A., W. G. Wolfe, and M. L. Salin. 1978.
Alterations in cellular enzymes and tissue metabolism in the oxygen toxic primate lung. J. Surg. Res. 24: 359-365.

17. Crapo, J. D., and J. M. McCord. 1976. Oxygen-induced changes in pulmonary superoxide dismutase assayed by antibody titrations. Am. J. Physiol. 231: 1196-1203.

18. Deneke, S. J., S. P. Bernstein, and B. L. Fanburg. 1979. Enhancement by disulfram (Antabuse) of toxic effect of 95 to $97 \% \mathrm{O}_{2}$ on the rat lung. J. Pharmacol. Exp. Ther. 208: 377-380.

19. Heikkila, R. E., F. S. Cabbat, and G. Cohen. 1976. In vivo inhibition of superoxide dismutase in mice by diethyldithiocarbamate. J. Biol. Chem. 251: 2182-2185.

20. Stevens, J., and A. P. Autor. 1977. Induction of superoxide dismutase by oxygen in neonatal rat lung. J. Biol. Chem. 252: 3509-3514.

21. Zweifach, B. W. 1961. Aspects of comparative physiology of laboratory animals relative to the problem of experimental shock. Fed. Proc. 20: 18-29.

22. Berry, L. J. 1977. Bacterial toxins. CRC Crit. Rev. Toxicol. 5: 239-318.

23. Shtasel, T. F., and L. J. Berry. 1969. Effects of endotoxin and cortisone on synthesis of ribonucleic acid and protein in livers of mice. J. Bacteriol. 97: 1018-1025.

24. Raffin, T. A., W. Douglas, L. M. Simon, J. Theodore, and E. D. Robin. 1977. Effects of hyperoxia on ultrastructure and superoxide dismutase (SOD) activity in cultured type II pneumocytes. Clin. Res. 25: 422A. (Äbstr.)

25. Forman, H. J., H. Berman, L. Furia, and A. Fisher. 1979. Increased mitochondrial superoxide dismutase in lung type II epithelial cells from oxygen exposed rats. Fed. Proc. 38: 1436. (Abstr.)

26. Hassan, H. M., and I. Fridovich. 1977. Regulation of the synthesis of superoxide dismutase in Escherichia coli: the glucose effects. J. Bacteriol. 132: 505-510.

27. Hassan, H. M., and I. Fridovich. 1977. Regulation of the synthesis of superoxide dismutase in Escherichia coli: induction by methyl viologen. J. Biol. Chem. 252: $7667-7672$. 